\title{
PATTERNS OF INTERNATIONAL FRAGMENTATION OF PRODUCTION AND THE RELATIVE DEMAND FOR LABOR'
}

\author{
Rodolfo Helg ${ }^{*}$, Lucia Tajoli ${ }^{\#}$
}

\section{Introduction}

Recently, both theoretical and applied research have devoted increasing attention to the fact that large and growing shares of international trade flows consist of intermediate and unfinished goods shipped from one country to another to combine manufacturing or services activities at home with those performed abroad. The new configuration of the productive structure underlying such phenomena has been named "internationally fragmented." Interest in international fragmentation of production (IFP) is due to the many - sometimes unexpected effects it has on the organization of production, trade flows and international specialization, the distribution of income and labor markets.

The existing (but limited) empirical work in this field suggests that differences in factor prices, and labor cost differentials especially, are one of the main driving forces of international fragmentation. In Europe, the persistent wage gap between EU older members and countries in Eastern Europe and in the Mediterranean Basin explains to a large extent the decision by EU firms to transfer abroad more or less extensive segments of previously integrated production processes. But geographic and cultural proximity also plays a key role in the choice of localization. In many industries, delocalization of production appears to be a response to the increasing competitive pressure exerted by low-cost producers on European firms (Baldone et al., 2002).

Starting from these findings, the purpose of our work is to analyze the labor market effects of cross-border fragmentation of production in Europe. Models of trade due to fragmentation of production indicate that, when international fragmentation takes place, we can observe a change in the factor proportion in the affected industries. But theoretical models of IFP indicate also that the sign of the effects of fragmentation on labor demand is a priori ambiguous, as it 
depends upon the factor intensity of the industries that fragment production, and on which production phases are delocalized. Therefore, the effects of fragmentation on labor markets turn out to be an empirical matter. We want to test if this shift in factor use is observable in Europe and it is related to fragmentation. We provide empirical evidence on the relationship between delocalization of production phases and the composition of employment in European countries.

The issue is not new and it is linked to the extensive debate on the relationship between globalization and the labor markets, which generated a large number of theoretical and empirical studies. In particular, a recent strand of literature focused on the impact of outsourcing and imports of intermediate goods on the labor market and on wage differentials. Earlier work on these issues by Feenstra and Hanson $(1996,1999)$ and Hanson (1996) focused on the U.S., which saw an increase in international fragmentation as trade in parts and intermediates with a number of comparatively low-wage countries (Mexico, first of all) was facilitated by the decline in commercial barriers. Europe experienced a similar phenomenon, especially thanks to the reintegration of the formerly planned economies of Central and Eastern Europe into world markets. A few recent papers examine the impact of fragmentation on labor markets in some European countries (Anderton and Brenton, 1999; Dell'mour et al., 2000; Gorg et. al., 2001; Strauss-Kahn, 2004).

The specific contribution of this paper is to extend the investigation to the cases of Italy and Germany, two countries that are highly involved in trade with Central and Eastern Europe. The paper uses a strictly defined measure of international fragmentation of production - trade flows for reasons of processing - that allows us to pinpoint the international linkages between production phases much better than general indices of import penetration employed in other analyses.

The empirical methodology is based on the work by Berman et al. (1994), who identify the causes of changes in the demand for skilled labor in the U.S. Their main candidates are increased international competition and labor-saving technological change. It is not straightforward to disentangle the effects of international trade and technological change, because international fragmentation may entail both changes in technology and increases in trade flows. If a given amount of final output is obtained with a smaller amount and/or a different proportion of domestic factors of production combined with foreign factors of production, IFP will appear in the data as a specific form of technological change, accompanied by a parallel increase in imports of intermediate or semi-finished goods. Therefore, for countries highly involved in international fragmentation, the distinction between "trade effects" and "technology effects" on labor demand might be inappropriate. We rather see IFP as a distinct - 
and to a large extent measurable - cause of shifts in labor demand, possibly in addition to other forms of technological change and "traditional" trade.

The paper is organized as follows: the next section provides the theoretical background for our empirical investigation; section three presents the data set and the stylized facts on international fragmentation of production and on the change in skilled/unskilled ratio in production in Italy and Germany. Section four is devoted to the econometric analysis of the relationship between IFP and changes in skill ratios, in order to assess whether fragmentation has changed the demand for skilled and unskilled labor in the countries examined; the main conclusions are presented in section five.

\section{International fragmentation and income distribution}

International fragmentation of production is defined as the process whereby previously integrated production activities are segmented and spread over an international network of production sites. The coordination of production activities taking place in different countries is likely to require some extra costs to pay for the needed services: transportation of goods between production locations, quality control, etc. (Jones and Kierzkowski, 2001). As long as integrated production remains available, fragmentation of production will be adopted only if it does not increase overall production costs, and even more so if it is a cost-saving strategy. Therefore, specific circumstances are required for fragmentation to take place, as additional coordination costs must be offset by a reduction in other production costs. ${ }^{2}$ International fragmentation of production can save costs mainly for two reasons: at given factor costs, the sum of segments of production needed to obtain the final good absorbs fewer production factors than integrated production (in which case, fragmentation would be a form of technical progress); or factor-price differentials between countries allow at least one fragment to be produced more cheaply in another country (Deardorff, 2001b).

Here we will focus on the second case, which can arise when countries lie in different cones of diversification, so that even when trading, factor price differences will persist between them. In this case, producing different fragments of a final good in two different countries allows firms to arbitrage factor-price differentials. In a Heckscher-Ohlin framework, the larger the factor-prices differentials and the more different are factor intensities in the two segments, the more fragmentation will reduce costs. Even if there are coordination expenses, the fragmented technology may still reduce overall production costs as long as factor intensities and factor-price differentials are sufficiently large. ${ }^{3}$

If the fragmented technology is adopted, the skill-abundant country will produce the skillintensive components, while the low-skill-intensive activities will be moved to the skill-scarce 
country. Therefore, trade flows will change between the countries involved, as intermediate goods are shipped from one production location to another.

Not only trade flows will be affected. The industries involved might increase or decrease total output, depending upon the adjustments taking place, ${ }^{4}$ and will change overall employment accordingly, but there will initially be an increase in the relative demand for the abundant factor. As emphasized by Deardorff (2001b) and Kohler (2004), among others, if the industry experiencing fragmentation is large enough compared to the overall economy, it will affect equilibrium in other sectors through its effects on relative wages or employment. Taking into account the general-equilibrium effects, the change in relative factor prices depends on how the factor proportions of fragments compare to the average factor intensities within the country's cone. Therefore, international fragmentation of production need not harm unskilled workers in skill-abundant countries.

The ambiguity of the distributive consequences of international fragmentation persists also in a specific-factors model. As shown by Kohler (2001), without international factor mobility and with sector-specific capital, the effect of outsourcing on the wage rate crucially depends on the factor-intensity assumption for the outsourced and non-outsourced fragment. In general, the effect will be stronger, the larger the fragmenting sector is in terms of its share on overall labor demand, and the more pronounced the factor-intensity difference between fragments within the sector. $^{5}$

Earlier empirical work on individual countries sometimes confirms and sometimes finds no evidence of a relationship between IFP and relative factor prices or factor demands. A study of the European Union by Egger and Egger (2001), in line with theory, finds that the effect of fragmentation on the skilled/unskilled ratio depends critically on the skill intensity of the outsourcing industry and that multiple outcomes are possible. But given that the European Union is itself a combination of very different economies, we examine separately the effects of international fragmentation on production and employment in Italy and Germany.

\section{Empirical evidence on international fragmentation of production}

\subsection{Data on international fragmentation of production and skill employment}

We begin our empirical analysis by examining a broad picture of outward fragmentation in Italy and Germany, ${ }^{6}$ two very active countries in IFP especially toward Central and Eastern Europe. The object is to determine the sectors in which it is most prevalent, being the characteristics of the sectors crucial in determining the final effects. 
We focus on a very narrow measure of IFP, namely, outward processing trade (OPT). The Comext database from Eurostat collects trade flows registered as "trade for reasons of processing" (goods temporarily exported from EU to be processed abroad and eventually reimported into the EU) using the Combined Nomenclature and the definitions adopted by EU legislation. OPT data provide a conservative and not exhaustive measure of the phenomenon of international fragmentation (as not all trade in intermediate and unfinished goods to be processed abroad is recorded as OPT according to Eurostat definition), but we believe that these are the most reliable data available for Europe at a highly disaggregated level, both sectorally and geographically. Furthermore, such a narrow measure should give us a better picture of the specific phenomenon we want to observe: not the general recourse to international outsourcing, but a re-organization of the production process toward what is sometimes called "production sharing", in which a firm not only buys intermediate inputs abroad, but it chooses to delocalize abroad a specific segment of its production, deciding exactly which phases of production are delocalized and how the processing is done abroad. This choice should have a very direct impact on the firm's demand for domestic factors.

To assess which industries are most affected by IFP, the disaggregated OPT data from Eurostat were re-aggregated to obtain a classification comparable to the standard classification of industrial activities (ISIC). With this new classification of OPT data we compute the ratio of the value of re-imported goods that were processed abroad to the value of domestic production. ${ }^{7}$ It is clear that in many industries this new form of organization of production is non-negligible even with such a narrow indicator.

The other key variable in our analysis is relative employment of skilled and unskilled workers. We consider this variable rather than wage differentials between groups of workers for two reasons: first, the direct impact of delocalization decisions by firms should be on employment composition; and, second, in Europe labor-market characteristics imply that wages are not very responsive (at least in the short-to-medium run) to changes in demand. ${ }^{8}$ Therefore, we expect relative employment to be more sensitive than wages to changes such as the international fragmentation of production.

Data on employment by industry are taken from national publications for 20 manufacturing sectors. The maximum level of disaggregation corresponds to 2-digit ISIC rev.3. We have data on employment of managers and employees (white-collars), and laborers and apprentices (bluecollars) at the industry level in Italy and Germany. These series allow us to examine how employment changes over time. We thus follow the literature in distinguishing between production and non-production workers. It is well-known that changes in the ratio of nonproduction and production workers are an incomplete representation of changes in 
skilled/unskilled workers, because skill upgrading might occur both for production and nonproduction workers, and type of occupation and skill endowment are only imperfectly correlated.

\subsection{The role of international fragmentation of production}

During the 1990s, the share of trade linked to international fragmentation in total trade flows and domestic production in Europe showed an upward trend. Between 1988 and the mid-90s, the share of registered EU re-imports (imports of goods previously temporarily exported to be processed) in 'normal' imports of goods doubled to $2.7 \%$. The overall figure is not very high, except that OPT appears to be concentrated in a few specific sectors. ${ }^{9}$ On average, Germany shows a higher propensity to use IFP than Italy: for the entire manufacturing sector, the ratio of OPT re-imports over domestic production is $1.5 \%$ in Germany and $0.7 \%$ in Italy. Both for Germany and Italy, we can observe basically two groups of sectors where international fragmentation plays a significant role in total production. 

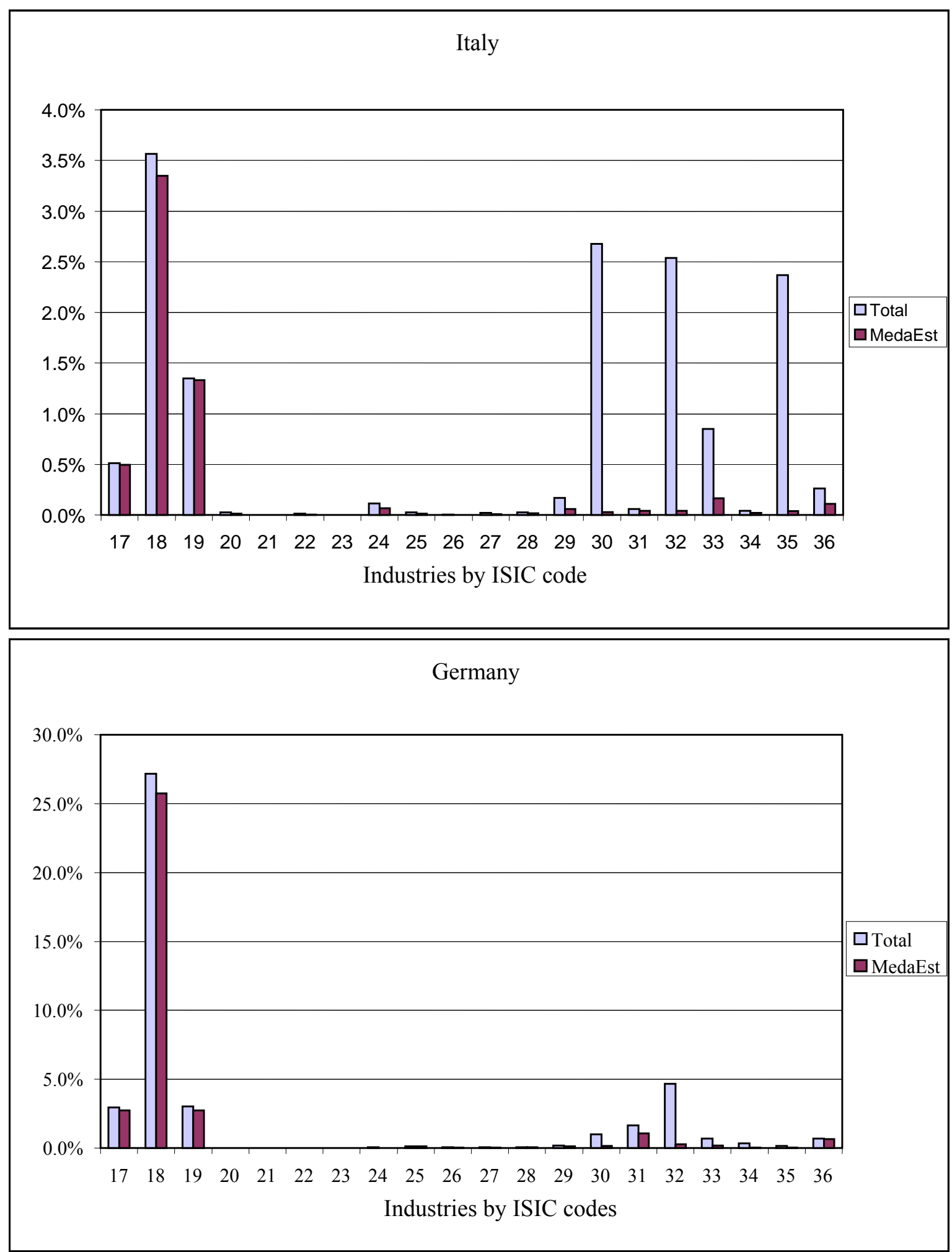

Fig. 1. Italian and German re-imports over domestic production in 1996.

Note: "Total" refers to the ratio of re-imports from all geographical areas over domestic production, while "MedaEst" refers to the ratio of re-imports from countries in the Mediterranean Basin and in Central and Eastern Europe (see Appendix B for the exact definition of the area and for industry classifications). Source: our calculations on Eurostat, Istat and OECD data. 
There is a group of so-called traditional sectors (namely textiles, apparel, shoes and to a smaller extent furniture), where production phases have become increasingly diversified in terms of factor intensity, and for which unskilled labor is the main factor of production in at least one phase. These are the sectors most subject to international fragmentation. In Germany, the practice to process abroad a large share of apparel production (code 18) started more than a decade ago, and re-imports of apparel amounted to more than $25 \%$ of domestic production in 1996, i.e., more than a quarter of German apparel was processed abroad. In Italy, the apparel sector is also the most affected, even if to a much smaller extent. In both countries, over time it is possible to observe an increase in the use of OPT in a number of sectors, with the particularly evident case of the apparel industry (code 18). In Italy, upward trends in the relevance of OPT also characterize textiles (code 17) and footwear (code 19), while in Germany the latter has reduced OPT.

The second group for which OPT is relevant is composed of relatively advanced industries: office machinery, communication equipment, precision instruments, and transport equipment. The reasons for IFP in these industries are probably different than in the traditional sectors. Here too, some production phases - such as assembly - have become increasingly standardized and more intensive in unskilled labor. But in these advanced sectors, fragmentation could also be driven by technological differences among countries and by technological inter-linkages, rather than by factor-cost differentials. In both Italy and Germany, the communication equipment industry is the most involved in the use of IFP within this second group, showing an increasing trend in OPT until the mid-1990s, but a slowdown in the last year of the sample.

The existence of dissimilarities between IFP in different industries is confirmed by evidence on the geographical origin of OPT flows. We expect the nature of OPT toward low-wage countries to be different from OPT toward countries with similar endowments and factor costs. Fig. 1 distinguishes OPT with the CEECs from countries located on the southern shore of the Mediterranean basin. These countries display a number of characteristics that make them a favorable location for some production phases: they are geographically close to the EU, reducing transport and coordination costs, and they are characterized by labor abundance and low labor costs relative to the EU. Furthermore, trade agreements with the CEECs and with some Mediterranean countries have reduced barriers between them and the EU. 
Indeed, most of OPT in textiles, apparel, footwear and furniture takes place in the CEECs
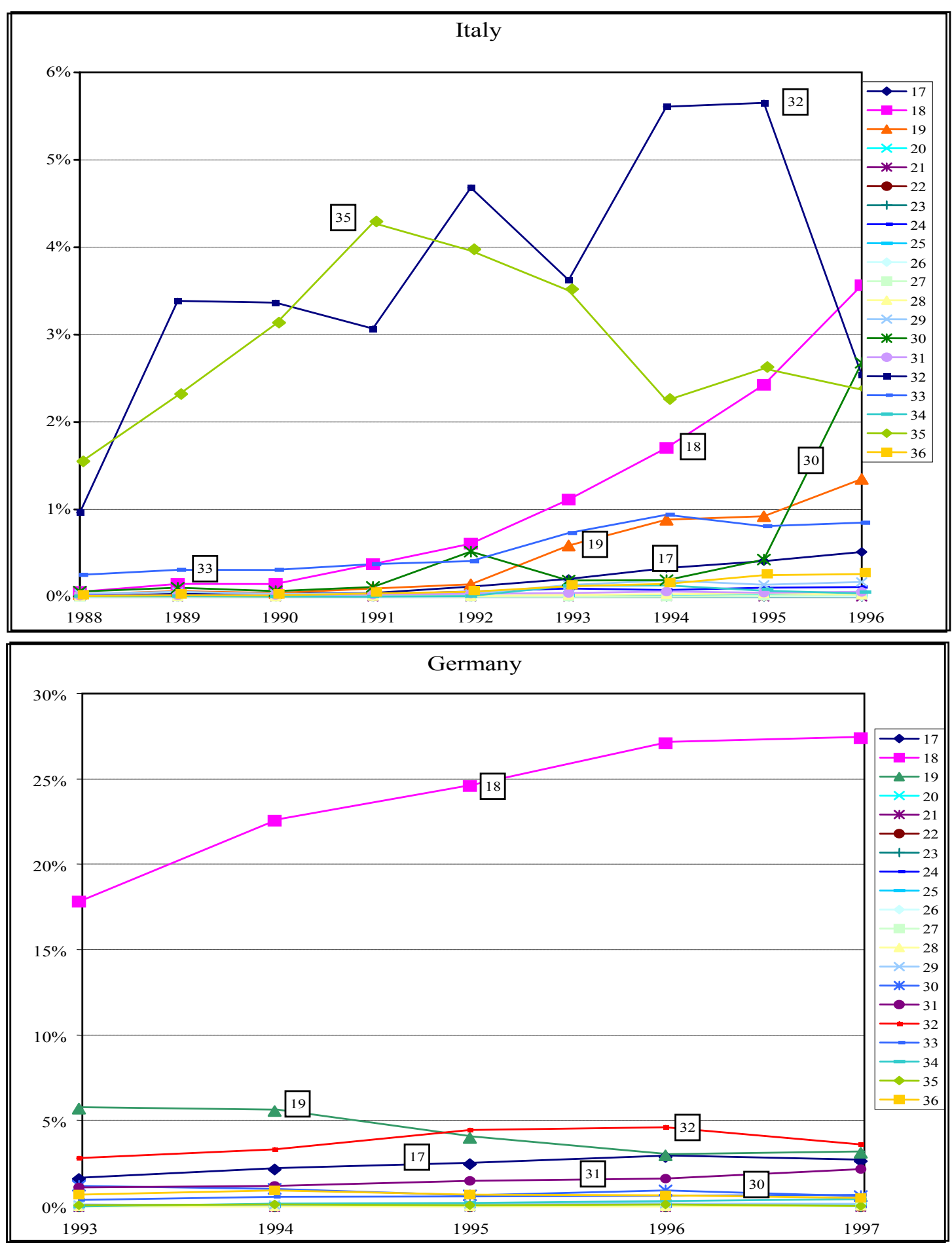

Fig. 2. Italian and German re-imports over domestic production by industry. Source: our calculations on Eurostat, Istat and OECD data. 
and the countries of the Mediterranean basin. The share of these countries in Italian and German OPT is quite high as well in the electrical machinery industry (where the assembly phases are low-skill-intensive), but it is very small in advanced industries, such as communication equipment.

It is also interesting to observe that in the last decade there has been a reorientation of Italian and German OPT - especially in traditional industries - toward the CEECs and the Balkans, at the expense of the Mediterranean countries. This reorientation indicates that IFP location is not determined uniquely by wage differentials. During the 1990s, wages in most of the CEECs rose relative to wages in the Mediterranean Basin, which therefore should still be preferred for delocalization if we were to consider only this variable. ${ }^{10}$ The observation is relevant, because if wage differentials are not the only reason behind IFP, this can affect the impact of IFP on the labor market.

\subsection{The change in the relative demand for labor}

A number of studies have shown, that in many countries there has been a shift over time in labor demand toward skilled workers. This occurred not only because of the increasing weight of technology-intensive sectors in manufacturing and of advanced services in the tertiary sector, but especially because within a number of industries production became more skill-intensive (Berman et al.,1994; Strauss-Kahn, 2004). Italy and Germany are no exception in this respect, showing a tendency to increase the skilled-to-unskilled ratio in their work force both at the aggregate and at the industry level. ${ }^{11}$

For the entire manufacturing sector, Germany has a slightly higher white-to-blue collar ratio than Italy (about 0.65 and 0.55 , respectively), but in both countries we observe a similar upward trend. The ratio increased moderately in German and Italian manufacturing over the observation period, as a result of the small reduction in blue collars employment and the stronger increase of white-collar employment (see Fig. 3). 

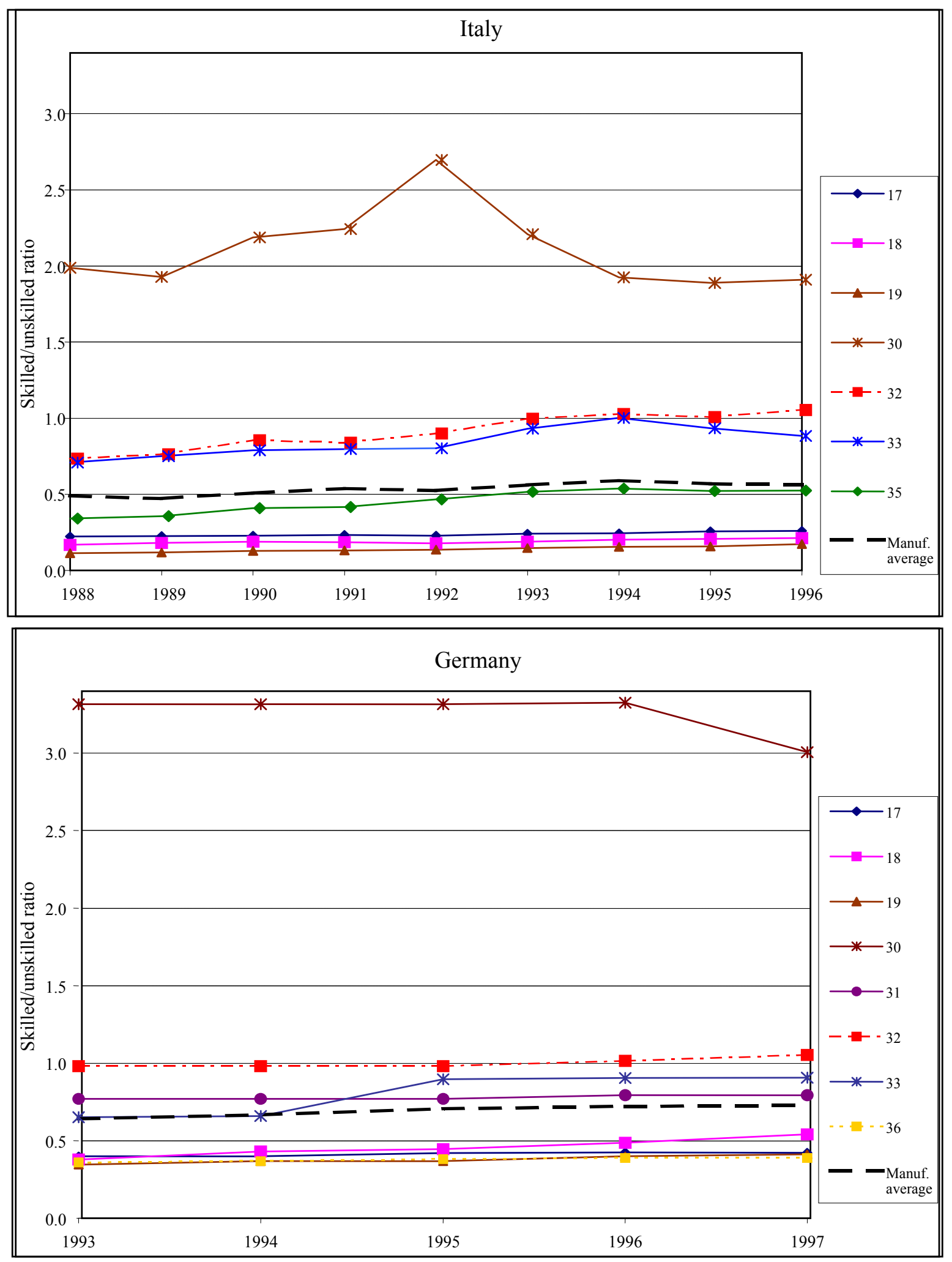

Fig. 3. Relative employment of skilled and unskilled workers in Italy and Germany in selected industries. Source: our calculations on Istat and Statistisches Bundesamt data. 
Such upward tendency is common to most sectors, with a few exceptions in both countries, in which the skilled/unskilled labor ratio declines slightly during the observation period. These are office machinery, electrical machinery and motor vehicles in Italy and basic metals and office machinery in Germany. In these advanced sectors, the falling ratio of skilled/unskilled workers seems to be due to the overall decline of employment in the industry, which shed relatively more white-collar workers. In contrast, the upward trend in the use of skilled labor is evident not only in high-tech sectors, such as telecommunication equipment and aircraft equipment, but also in very traditional sectors, such as apparel and furniture.

The sectors most affected by IFP (textile, apparel and footwear) can be considered unskilledlabor-intensive industries, as the ratio of skilled over unskilled workers is lower than the average ratio for manufacturing industries. This is especially true for Italy. In spite of the upward trend in skilled-labor employment, in Italy the apparel and footwear industries (series 18 and 19 in Fig. 3) still display a skilled/unskilled ratio that is less than half the average of the manufacturing sector. In Germany, the skilled/unskilled ratio shows considerable variation in the apparel sector, while this is not the case for the textile and footwear industries. The German apparel industry, which started to delocalize segments of production nearly twenty years ago, currently displays a much higher skilled/unskilled ratio than the Italian one ( 0.54 and 0.21 in Germany and Italy, respectively). These traditional industries in Germany are now much closer to the manufacturing sector average in terms of skilled/unskilled employment. ${ }^{12}$

While informative, the preliminary evidence does not allow us to conclude whether in general there is a relationship between OPT and the degree of skill-intensity. We now examine this issue more closely.

\section{Econometric analysis}

To examine the impact of IFP on relative factor demands, it seems appropriate to estimate a function that shows how the access to this organization of production has affected firms' choices. The recent literature on the role of international trade and international outsourcing on relative wages and labor demand uses a quasi-fixed translog cost function (Brown and Christensen, 1981) with two variable factors, skilled and unskilled labor, and capital as a quasifixed factor. Then, the short run cost function when the levels of capital and output are fixed is given by the following general expression:

$$
\begin{array}{r}
\ln \mathrm{C}=\alpha_{0}+\Sigma_{\mathrm{i}} \alpha_{\mathrm{i}} \ln \left(\mathrm{w}_{\mathrm{i}}\right)+\Sigma_{\mathrm{k}} \beta_{\mathrm{k}} \ln \left(\mathrm{x}_{\mathrm{k}}\right)+1 / 2 \Sigma_{\mathrm{i}} \Sigma_{\mathrm{j}} \gamma_{\mathrm{ij}} \ln \left(\mathrm{w}_{\mathrm{i}}\right) \ln \left(\mathrm{w}_{\mathrm{j}}\right)+ \\
+1 / 2 \Sigma_{\mathrm{k}} \Sigma_{\mathrm{l}} \delta_{\mathrm{kl}} \ln \left(\mathrm{x}_{\mathrm{k}}\right) \ln \left(\mathrm{x}_{\mathrm{l}}\right)+\Sigma_{\mathrm{i}} \Sigma_{\mathrm{k}} \varphi_{\mathrm{ik}} \ln \left(\mathrm{w}_{\mathrm{i}}\right) \ln \left(\mathrm{x}_{\mathrm{k}}\right),
\end{array}
$$


where $\mathrm{C}$ represents production costs, $\mathrm{w}_{\mathrm{i}}\left(\right.$ or $\mathrm{w}_{\mathrm{j}}$ ) denote the prices of the optimally chosen variable inputs (here $\mathrm{i}, \mathrm{j}=$ skilled and unskilled labor, respectively) and $\mathrm{x}_{\mathrm{k}}\left(\right.$ or $\mathrm{x}_{\mathrm{l}}$ ) denotes either the quantities of the fixed inputs (here only capital) or any other shift variables (for example output), while $\alpha, \beta, \gamma, \delta, \varphi$ are given technology parameters.

Imposing cost minimization and some parameter restrictions to make the function linearly homogeneous in factor prices generates the factor-share equations that are usually estimated. In the literature, some papers estimate these cost share equations (see, for example, Feenstra and Hanson 1996, 1999 for the U.S.; Gorg et. al., 2001, for UK; Hansson, 2001, for Sweden). Another branch of the literature (see, for example, Brenton and Pinna, 2001, for Italy; StraussKahn, 2004, for France; Anderton et al., 2001, for Sweden; and Egger et al. 2001, for Austria) has estimated employment-share equations. ${ }^{13}$ In this paper, we adopt the latter approach, and following Feenstra and Hanson's (2001) suggestion, we introduce an index of IFP as a shift variable in the following skilled-employment-share equation:

$$
S_{i t}=\beta_{0}+\mu_{i}+\lambda_{t}+\beta_{1} F_{i t}+\beta_{2} Y_{i t}+\beta_{3}\left(K_{i t} / Y_{i t}\right)+\beta_{4}\left(W_{s k} / W_{\text {unsk }}\right)+\varepsilon_{i t}
$$

where $\mathrm{S}$ is the ratio of skilled (Ssk) and unskilled workers (Sunsk) employed in industry $\mathrm{i}$ at time $\mathrm{t}, \mathrm{K}$ is the net capital stock of industry $\mathrm{i}, \mathrm{Y}$ is gross output of industry i, F is our fragmentation index (re-imports over gross domestic output), $\mathrm{W}$ is the wage rate, and $\mu \mathrm{i}$ and $\lambda \mathrm{t}$ are group specific (industry and time, respectively) fixed effects.14 Logarithmic transformation has been applied to all variables. We estimate Eq. 2 in levels 15 across industries and time, and adopt a dynamic specification via the introduction in Eq. 2 of the lagged dependent variable.16 This specification allows us to preserve the information contained in the levels of the variables, while taking into account the dynamics of the phenomenon.

Results are presented in Table 1 for the dynamic version of Eq. 2, with the restriction that $\beta 4$ $=0.17 \mathrm{We}$ have adopted a two-way fixed-effects specification. The presence of the lagged dependent variable generates inconsistency of the within estimator (or least squares dummyvariable estimator - LSDV) for large N (number of sectors) and small T (number of years). The usual solution in this case is to adopt some kind of generalized-method-of-moments (GMM) estimator. Our empirical set up, however, is one in which both $\mathrm{N}$ and $\mathrm{T}$ are small of the same magnitude and the properties of the various estimators are less clear-cut.18 We produce results for both the two-way LSDV estimator and for the Arellano-Bond GMM estimator.

The results are reported in columns 1 and 2 for Italy and columns 3 and 4 for Germany.19 The significance of sector- and time-fixed effects is confirmed by the F-tests reported at the bottom of the table. In the estimates for Italy, the coefficient of the index of fragmentation is significantly positive. This positive sign is in line with our expectations, and tends to confirm 
our hypothesis that the Italian manufacturing sectors use fragmentation of production first of all to shift abroad phases of production that are relatively less skill-intensive. Therefore, in those industries the employment share of skilled labor tends to increase.

Table 1 - Regression results for skilled employment share

\begin{tabular}{|c|c|c|c|c|}
\hline & $\begin{array}{c}\text { Eq 1.1 } \\
\text { Italy }\end{array}$ & $\begin{array}{c}\text { Eq 1.2 } \\
\text { Italy }\end{array}$ & $\begin{array}{c}\text { Eq 1.3 } \\
\text { Germany }\end{array}$ & $\begin{array}{c}\text { Eq 1.4 } \\
\text { Germany }\end{array}$ \\
\hline LSDV2 & GMM-AB & LSDV2 & GMM-AB \\
\hline $\operatorname{LnF}$ & $\begin{array}{c}0.01 \\
(0.004)^{* *}\end{array}$ & $\begin{array}{c}0.01 \\
(0.002)^{* *}\end{array}$ & $\begin{array}{c}0.004 \\
(0.01)\end{array}$ & $\begin{array}{c}0.02 \\
(0.02)\end{array}$ \\
\hline $\ln (\mathrm{K} / \mathrm{Y})$ & -0.25 & -0.25 & 0.78 & 0.53 \\
$(0.10)^{* *}$ & $(0.10)^{* *}$ & $(0.32)^{* *}$ & $(0.52)$ \\
\hline LnY & -0.46 & -0.46 & 0.64 & 0.12 \\
& $(0.18)^{* *}$ & $(0.14)^{* *}$ & $(0.38)^{*}$ & $(0.67)$ \\
\hline $\operatorname{lnS}(-1)$ & 0.18 & 0.14 & 0.49 & 0.77 \\
& $(0.13)$ & $(0.19)$ & $(0.22)^{* *}$ & $(0.31)^{* *}$ \\
\hline No. of observations & 117 & 104 & 80 & 60 \\
\hline No. of sectors & 13 & 13 & 20 & 20 \\
\hline R-squared & 0.72 & & 0.56 & \\
\hline $\begin{array}{c}\text { F-test for time effects } \\
\text { (p-value) }\end{array}$ & $2.98^{* *}$ & & 1.78 & \\
\hline $\begin{array}{c}\text { F-test for sector effects } \\
\text { (p-value) }\end{array}$ & $6.42^{* *}$ & & $2.95^{* *}$ & \\
\hline $\begin{array}{c}\text { ABII } \\
\text { (p-value) }\end{array}$ & $(0.00)$ & & $(0.00)$ & \\
\hline
\end{tabular}

Note: heteroskedastic robust standard errors in parentheses.

Coefficients with a $* *, *$ are significant at the $5 \%$ and $10 \%$ level, respectively.

ABII: Arellano-Bond test for $\mathrm{H}_{0}$ : no second-order correlation in the residuals.

The sign of the capital/output ratio for Italy in this equation is negative and significant. A priori, the sign of this variable was uncertain, as it would depend on the complementarity or substitutability between capital and skilled labor. Estimates of similar equations for other countries yield positive as well as negative signs for the capital variable (see, for example, Strauss-Kahn, 2004 for the case of France).$^{20}$ In the Italian case, the negative sign indicates substitutability between capital and skills. Also, the output variable is negative and significant. This variable controls for the scale of production and its sign indicates that as production scale increases, the employment of blue-collar workers increases more rapidly than that of whitecollar workers. ${ }^{21}$

For Italy, the results are robust across estimators. Results for the fragmentation variable are also relatively robust with respect to fixed effects (see Tables A1 and A2). In contrast, the results for the output variable and the capital/output ratio are very sensitive to the inclusion of time dummies (Table A2). It is plausible that results in column 2 (POLS with no fixed effects) 
suffer from an omitted-variable bias due to the lack of a relative-wage variable. Controlling for time effects in column 1 should eliminate the bias, on the reasonable assumption that relative wages are constant across sectors.

Results are quite different for Germany. The coefficient of the index of fragmentation is not significant, while the capital/output variable and the scale variable have positive and significant coefficient. This difference in results between the two countries seems to indicate that the characteristics of the production process in the two countries are not at all the same. For example, it turns out that in Germany capital is complementary to skilled labor. ${ }^{22}$ The characteristics of the German production function and factor ratios for sectors involved in international fragmentation indicate that IFP does not affect relative labor demand.

As in other work, we introduce an industry-specific R\&D index as a proxy for the effect of technological change in the labor demand equation (Table 2). The addition of this variable does not change the results for Italy and the R\&D variable itself turns out to be non-significant. In the case of Germany, the introduction of this variable produces some change in the LSDV estimates, but no change in the GMM-AB ones. The R\&D coefficient is positive and significant. Therefore, in the German case, technological progress seems to be saving unskilled labor and using skilled labor.

Table 2 - Regression results for skilled employment share: with R\&D

\begin{tabular}{|c|c|c|c|c|}
\hline & $\begin{array}{c}\text { Eq 2.1 } \\
\text { Italy }\end{array}$ & $\begin{array}{c}\text { Eq 2.2 } \\
\text { Italy }\end{array}$ & $\begin{array}{c}\text { Eq 2.3 } \\
\text { Germany }\end{array}$ & $\begin{array}{c}\text { Eq 2.4 } \\
\text { Germany }\end{array}$ \\
\hline & LSDV2 & GMM-AB & LSDV2 & GMM-AB \\
\hline $\ln F$ & 0.009 & 0.006 & -0.002 & 0.01 \\
& $(0.004)^{* *}$ & $(0.002)^{* *}$ & $(0.01)$ & $(0.02)$ \\
\hline $\ln (\mathrm{K} / \mathrm{Y})$ & -0.24 & -0.24 & 0.67 & 0.25 \\
& $(0.10)^{* *}$ & $(0.12)^{*}$ & $(0.33)^{* *}$ & $(0.53)$ \\
\hline $\ln \mathrm{-}$ & -0.47 & -0.48 & 0.63 & 0.02 \\
& $(0.18)^{* *}$ & $(0.14)^{* *}$ & $(0.39)$ & $(0.62)$ \\
\hline $\ln \mathrm{R} \& \mathrm{D}$ & 0.003 & -0.007 & 0.11 & 0.19 \\
& $(0.008)$ & $(0.01)$ & $(0.05)^{* *}$ & $(0.09)^{* *}$ \\
\hline $\ln \mathrm{C}(-1)$ & 0.16 & 0.12 & 0.47 & 0.77 \\
& $(0.14)$ & $(0.20)$ & $(0.22)^{* *}$ & $(0.26)^{* *}$ \\
\hline No. of obs. & 108 & 96 & 80 & 60 \\
\hline No. of sectors & 12 & 12 & 20 & 20 \\
\hline R-squared & 0.72 & & 0.58 & \\
\hline F-test for time effects & 2.57 & & 5.7 & \\
(p-value) & $(0.01)$ & & $(0.00)$ & \\
\hline F-test for sector effects & 4.40 & & 1.90 & \\
(p-value) & $(0.00)$ & & $(0.14)$ & \\
\hline ABII & & -1.02 & & 0.11 \\
(p-value) & & $(0.31)$ & & $(0.91)$ \\
\hline
\end{tabular}

Note: see Table 1. 
As a test of the robustness of our results for Italy, we also estimate the cost-share equation in its original form, without reparameterization (Table 3). ${ }^{23}$ The results are in line with our expectations, given the results in Table 1. All the control variables maintain signs and significance, and in particular the coefficient of the fragmentation index remains positive and significant.

Table 3 - Regression results for cost share specification (dependent variable: log of cost share of skilled labor in the total wage bill - CS)

\begin{tabular}{|c|c|c|c|c|}
\hline & $\begin{array}{c}\text { Eq. 3.1 } \\
\text { Italy }\end{array}$ & $\begin{array}{c}\text { Eq. 3.2 } \\
\text { Italy }\end{array}$ & $\begin{array}{c}\text { Eq. 3.3 } \\
\text { Italy }\end{array}$ & $\begin{array}{c}\text { Eq. 3.4 } \\
\text { Italy }\end{array}$ \\
\hline & LSDV2 & LSDV2 & LSDV2 & GMM-AB \\
\hline LnF & 0.005 & $0.005^{*}$ & $0.01^{* *}$ & $0.01^{* *}$ \\
& $(0.004)$ & $(0.003)$ & $(0.004)$ & $(0.001)$ \\
\hline Ln(K/Y) & -0.22 & $-0.26^{* *}$ & $-0.28^{* *}$ & $-0.25^{* *}$ \\
& $(0.15)$ & $(0.09)$ & $(0.10)$ & $(0.12)$ \\
\hline LnY & $-0.64^{* *}$ & $-0.60^{* *}$ & $-0.51^{* *}$ & $-0.41^{* *}$ \\
& $(0.24)$ & $(0.16)$ & $(0.17)$ & $(0.19)$ \\
\hline $\ln ($ wsk/wunsk) & & $1.07^{* *}$ & $0.95^{* *}$ & $0.97^{* *}$ \\
& & $(0.16)$ & $(0.17)$ & $(0.09)$ \\
\hline LnCS(-1) & & & 0.12 & 0.03 \\
& & & $(0.10)$ & $(0.11)$ \\
\hline No. of observations & 130 & 130 & 117 & 104 \\
\hline No. of sectors & 13 & 13 & 13 & 13 \\
\hline R-squared & 0.68 & 0.85 & 0.83 & \\
\hline F-test for time effects & 8.90 & 9.27 & 3.93 & \\
(p-value) & $(0.00)$ & $(0.00)$ & $(0.00)$ & \\
\hline F-test for sector effects & 1393.5 & 2643.5 & 10.68 & \\
(p-value) & $(0.00)$ & $(0.00)$ & $(0.00)$ & \\
\hline ABII & & & & -0.86 \\
(p-value) & & & & $(0.39)$ \\
\hline
\end{tabular}

Note: see Table 1.

\section{Conclusions}

The aim of this paper was to test the effects of international fragmentation of production on labor demand in Europe. Because of its characteristics, IFP is a form of organization of production very likely to be factor-biased and therefore it is expected to affect relative labor demands. In particular, we wanted to test if fragmentation undertaken especially in industries traditionally considered intensive in unskilled labor, favors skilled labor in Italy and in Germany.

Our empirical exercise shows that this is not always the case. In our estimates of the equation measuring labor demand, the index of international fragmentation is consistently positive and significant for Italy, implying that part of the increase in the skilled-to-unskilled labor ratio in 
Italy is due to this phenomenon. For Germany, on the other hand, IFP appears not to influence the relative demand for skilled labor.

The contradictory results for Italy and Germany might appear puzzling, but they are very much in line with the theory of fragmentation, which shows that the impact depends on the nature and the context of fragmentation. Theoretical models show that the net effect of IFP on the labor market depends upon which phases of production are relocated, in which industries and toward which countries relocation takes place, and on how this affects the overall composition of output. The effect should be stronger when the fragmenting sector is larger and more distant from the country's average in terms of factor usage.

In Italy, the weight of traditional sectors resorting to IFP is high and they are characterized by low skilled/unskilled ratios. Therefore, we expect IFP to play a role there. Our results show that such an impact exists, even if small. In Germany, the industries most affected by IFP have skilled/unskilled ratios much closer to the national manufacturing average, so that IFP in those industries on average does not have a strong impact on labor demand. Our empirical results confirm that even in advanced, skill-abundant countries, IFP designed to arbitrage labor-cost differentials will not necessarily widen inequalities between workers.

Use, in this paper, of a strictly defined measure of fragmentation such as OPT underestimates the more general phenomenon of outsourcing. Nevertheless, we believe that our results are pertinent to the issue of income distribution. By allowing firms to pick the exact segments of production they want to relocate, OPT should capture specifically firms' decisions pertaining to the re-organization of production and the optimal choice of factors of production. Therefore, we expect it to be the measure that most directly affects the relative demand for labor. 


\section{References}

Anderton, R., \& Brenton, P. (1999). Outsourcing and low-skilled workers in the UK. Bulletin of Economic Research, 51, 267-286.

Anderton, R., Brenton, P., \& Oscarsson, E. (2001, March). What's trade got to do with it? Relative demand for skills within Swedish manufacturing. CEPS Working Document No. 162.

Antràs, P., \& Helpman, E. (2004). Global sourcing. Journal of Political Economy, 112(3), 552580.

Arndt, S. W., \& Kierzkowski, H. (2001). Fragmentation. New production patterns in the world economy, Oxford: Oxford University Press.

Baldone, S., Sdogati F., \& Tajoli, L. (2001). Patterns and determinants of international fragmentation of production. Evidence from outward processing trade between the EU and the countries of Central-Eastern Europe. Weltwirtshaftliches Archiv, 80-104.

Baldone, S., Sdogati, F., \& Tajoli, L. (2002). Moving to Central-Eastern Europe: fragmentation of production and competitiveness in the European textile and apparel industry. Rivista di Politica Economica, XCII(1-2), 209-281.

Berman, E., Bound, J., \& Griliches, Z. (1994). Changes in the demand for skilled labor within U.S. manufacturing: evidence from the annual survey of manufacturers. Quarterly Journal of Economics, 109(2), 367-397.

Brenton, P., \& Pinna, A.M. (2001). The declining use of unskilled labour in Italian manufacturing: is trade to blame? CEPS Working Document No.178.

Brown, R., \& Christensen, L. (1981). Estimating elasticities of substitution in a model of partial static equilibrium: an application to US agriculture 1947 to 1974. In Berndt, E., \& Fiel, B. (Eds.), Modeling and measuring natural resource substitution. Cambridge, MA: MIT Press.

Bruno, G.S.F. (2004). Estimation, inference and Monte Carlo analysis in dynamic unbalanced data models with a small number of individuals. Mimeo. Università Bocconi.

Bun, M. J.G., \& Kiviet, J. F. (2005). The effects of dynamic feedbacks on LS and MM estimator accuracy in panel data model. Journal of Econometrics, forthcoming.

Davis, D.R. (1998). Technology, unemployment and relative wages in a global economy. European Economic Review, 42, 1613-1633.

Deardorff, A.V. (2001a). Fragmentation in simple trade models. North American Journal of Economics and Finance, 12(2), 121-137.

Deardorff, A.V. (2001b). Fragmentation across cones. In Arndt, S.W., \& Kierzkowski, H. (Eds.), Fragmentation. New production patterns in the world economy (pp.35-51). Oxford: Oxford University Press.

Dell'mour, R., Egger, P., Gugler, K., \& Pfaffermayr, M. (2000, June). Outsourcing of Austrian manufacturing to Eastern European countries: effects on productivity and the labor market. In Arndt, S.W., Handler, H., \& Salvatore, D. (Eds.), Fragmentation of the value added chain, Vienna Conference.

Egger, H., \& Egger, P. (2001). Cross-border sourcing and outward processing in EU manufacturing. North American Journal of Economics and Finance, 12, 243-256. 
Egger, P., Pfaffermayr, M., \& Wolfmayr-Schnitzer, Y. (2001). The international fragmentation of Austrian manufacturing: the effects of outsourcing on productivity and wages. North American Journal of Economics and Finance, 12, 257-272.

Evans, C., \& Harrigan, J. (2003). Distance, time and specialization. NBER Working Paper No. 9729.

Feenstra, R.C. (1998). Integration of trade and disintegration of production in the global economy. Journal of Economic Perspectives, 12(4), 31-50.

Feenstra, R.C. \& Hanson, G.H. (1996). Globalization, outsourcing and wage inequality. American Economic Review, 86(2), 240-245.

Feenstra, R. \& Hanson, G.H. (1999). The impact of outsourcing and high-technology capital on wages: estimates for the United States, 1979-1990. Quarterly Journal of Economics, 114(3), 907-940.

Feenstra, R.C. \& Hanson, G.H. (2001, July). Global production sharing and rising inequality: a survey on trade and wages. NBER Working Paper No. 8372.

Gorg, H., Hijzen, A., \& Hine, R.C. (2001). International fragmentation and relative wages in the UK. Research Paper 2001/33, Leverhulme Centre, University of Nottingham.

Hanson, G.H. (1996). Localization economies, vertical organization and trade. American Economic Review, 86(5), 1266-1278.

Hansson, P. (2001, March). Skill upgrading and production transfer within Swedish multinationals in the 1990s. CEPS Working Document No.163.

Haskel, J.E. \& Slaughter, M. (2002). Does the sector bias of skill-biased technical change explain changing skill premia? European Economic Review, 46(10), 1757-1783.

Jones, R. \& Kierzkowski, H. (2001). A framework for fragmentation. In Arndt, S.W., \& Kierzkowski, H. (Eds.), Fragmentation. New production patterns in the world economy, Oxford: Oxford University Press.

Judson, R.A., \& Owen, A.L. (1999). Estimating dynamic panel data models: a guide for macroeconomists. Economics Letters, 65, 9-15.

Kohler, W. (2001). A specific-factor view on outsourcing. North American Journal of Economics and Finance, 12, 31-53.

Kohler, W. (2004). International outsourcing and factor prices with multistage production. Economic Journal, 114, C166-C185.

Markusen, J.R., \& Venables, A.J. (2003). The international organization of multi-state production. CEBR Discussion Paper 2003-24.

Strauss-Kahn, V. (2004). The role of globalization in the within-industry shift away from unskilled workers in France. In Baldwin, R.E., \& Winters, L.A. (Eds.), Challenges to globalization. NBER and University of Chicago Press. 


\section{Appendix A-Robustness checks}

Table A1 - Regression results for skilled employment share: static specification

\begin{tabular}{|c|c|c|c|c|}
\hline & $\begin{array}{c}\text { Eq A1.1 } \\
\text { Italy }\end{array}$ & $\begin{array}{c}\text { Eq A1.2 } \\
\text { Italy }\end{array}$ & $\begin{array}{c}\text { Eq A1.3 } \\
\text { Germany }\end{array}$ & $\begin{array}{c}\text { Eq A1.4 } \\
\text { Germany }\end{array}$ \\
\hline & LSDV2 & LSDV2 & LSDV2 & LSDV2 \\
\hline $\ln F$ & 0.005 & 0.005 & -0.02 & -0.02 \\
& $(0.003)^{*}$ & $(0.003)^{*}$ & $(0.03)$ & $(0.03)$ \\
\hline $\ln (\mathrm{K} / \mathrm{Y})$ & -0.26 & -0.22 & 1.52 & 1.37 \\
& $(0.09)^{* *}$ & $(0.10)^{* *}$ & $(0.51)^{* *}$ & $(0.50)^{* *}$ \\
\hline $\ln \mathrm{-}$ & -0.60 & -0.58 & 1.29 & 1.23 \\
& $(0.15)^{* *}$ & $(0.16)^{* *}$ & $(0.50)^{* *}$ & $(0.50)^{* *}$ \\
\hline $\ln \mathrm{R} \& \mathrm{D}$ & & -0.003 & & 0.08 \\
& & $(0.01)$ & & $(0.04)^{*}$ \\
\hline No. of observations & 130 & 120 & 100 & 100 \\
\hline No. of sectors & 13 & 12 & 20 & 20 \\
\hline R-squared & 0.74 & 0.74 & 0.42 & 0.44 \\
\hline F-test for time effects & 10.1 & 7.9 & 5.7 & 5.8 \\
(p-value) & $(0.00)$ & $(0.00)$ & $(0.00)$ & $(0.00)$ \\
\hline F-test for sector effects & 2602.7 & 2401.6 & 387.6 & 193.3 \\
(p-value) & $(0.00)$ & $(0.00)$ & $(0.00)$ & $(0.00)$ \\
\hline
\end{tabular}

Note: heteroskedastic robust standard errors in parentheses. Coefficients with a **, ${ }^{*}$ are significant at the $5 \%$ and $10 \%$ level, respectively.

Table A2 - Regression results for skilled employment share: static - no heterogeneity and industry fixed effects

\begin{tabular}{|c|c|c|c|c|}
\hline & $\begin{array}{c}\text { Eq A2.1 } \\
\text { Italy }\end{array}$ & $\begin{array}{c}\text { Eq A2.2 } \\
\text { Italy }\end{array}$ & $\begin{array}{c}\text { Eq A2.3 } \\
\text { Germany }\end{array}$ & $\begin{array}{c}\text { Eq A2.4 } \\
\text { Germany }\end{array}$ \\
\hline & LSDV1 & POLS & LSDV1 & POLS \\
\hline const & -4.56 & -14.17 & -13.28 & -2.54 \\
& $(0.78)^{* *}$ & $(2.72)^{* *}$ & $(4.60)$ & $(3.16)$ \\
\hline $\ln F$ & 0.14 & -0.05 & 0.01 & -0.01 \\
& $(0.003)^{* *}$ & $(0.01)^{* *}$ & $(0.01)$ & $(0.02)$ \\
\hline $\ln (\mathrm{K} / \mathrm{Y})$ & 0.23 & 0.33 & 1.43 & 0.00 \\
& $(0.08)^{* *}$ & $(0.09)^{* *}$ & $(0.75)^{*}$ & $(0.07)$ \\
\hline $\ln \mathrm{O}$ & 0.40 & 2.44 & 1.02 & 0.42 \\
& $(0.09)^{* *}$ & $(0.58)^{* *}$ & $(0.68)$ & $(0.63)$ \\
\hline No. of observations & 130 & 130 & 100 & 100 \\
\hline No. of sectors & 13 & 13 & 20 & 20 \\
\hline R-squared & 0.47 & 0.24 & 0.17 & 0.01 \\
\hline F-test for sector effects & 1117.6 & & 93.3 & \\
(p-value) & $(0.00)$ & & $(0.00)$ & \\
\hline
\end{tabular}

Note: see Table A1. 
Table A3 - Regression results for skilled/unskilled employment: dynamic - no heterogeneity and industry fixed effects

\begin{tabular}{|c|c|c|c|c|}
\hline & $\begin{array}{c}\text { Eq A3.1 } \\
\text { Italy }\end{array}$ & $\begin{array}{c}\text { Eq A3.2 } \\
\text { Italy }\end{array}$ & $\begin{array}{c}\text { Eq A3.3. } \\
\text { Germany }\end{array}$ & $\begin{array}{c}\text { Eq A3.4 } \\
\text { Germany }\end{array}$ \\
\hline & LSDV1 & GMM-AB & LSDV1 & GMM-AB \\
\hline & -0.31 & 0.54 & -5.75 & 0.79 \\
$(0.89)$ & $(0.23)^{* *}$ & $(4.27)$ & $(0.53)$ \\
\hline $\ln \mathrm{F}$ & 0.01 & -0.001 & 0.01 & -0.01 \\
& $(0.004)^{* *}$ & $(0.002)$ & $(0.01)$ & $(0.01)$ \\
\hline $\ln (\mathrm{K} / \mathrm{Y})$ & -0.02 & -0.01 & 0.65 & -0.03 \\
& $(0.09)$ & $(0.01)$ & $(0.42)$ & $(0.01)^{* *}$ \\
\hline $\ln \mathrm{Y}$ & -0.05 & -0.11 & 0.37 & -0.14 \\
& $(0.08)$ & $(0.51)^{* *}$ & $(0.44)$ & $(0.11)$ \\
\hline $\ln (-1)$ & 0.52 & 1.00 & 0.56 & 0.99 \\
& $(0.10)^{* *}$ & $(0.01)^{* *}$ & $(0.22)^{* *}$ & $(0.02)^{* *}$ \\
\hline No. of observations & 117 & 117 & 80 & 80 \\
\hline No. of sectors & 13 & 13 & 20 & 20 \\
\hline R-squared & 0.63 & 0.99 & 0.48 & 0.96 \\
\hline F-test for sector effects & $4.52^{* *}$ & & $2.81^{* *}$ & \\
(p-value) & $(0.00)$ & & $(0.00)$ & \\
\hline
\end{tabular}

Note: see Table A1.

Table A4 - Regression results for skilled/unskilled employment: dynamic specification for Italy including the relative wage

\begin{tabular}{|c|c|c|}
\hline & $\begin{array}{c}\text { Eq A4.1 } \\
\text { Italy }\end{array}$ & $\begin{array}{c}\text { Eq A4.2 } \\
\text { Italy }\end{array}$ \\
\hline & LSDV2 & GMM-AB \\
\hline $\ln F$ & 0.01 & 0.01 \\
& $(0.004)^{* *}$ & $(0.002)^{* *}$ \\
\hline $\ln (\mathrm{K} / \mathrm{Y})$ & -0.24 & -0.25 \\
& $(0.10)^{* *}$ & $(0.10)^{* *}$ \\
\hline $\operatorname{lnY}$ & -0.46 & -0.47 \\
& $(0.18)^{* *}$ & $(0.14)^{* *}$ \\
\hline $\operatorname{Ln}($ Wsk/Wunsk) & -0.05 & -0.04 \\
& $(0.16)$ & $(0.48)$ \\
\hline $\operatorname{lnS}(-1)$ & 0.18 & 0.14 \\
& $(0.13)$ & $(0.19)$ \\
\hline No. of observations & 117 & 104 \\
\hline No. of sectors & 13 & 13 \\
\hline R-squared & 0.72 & \\
\hline $\begin{array}{c}\text { F-test for time effects } \\
\text { (p-value) }\end{array}$ & $3.81^{* *}$ & \\
\hline $\begin{array}{c}\text { F-test for sector effects } \\
\text { (p-value) }\end{array}$ & $6.00)$ & \\
\hline AB II & $(0.00)$ & \\
\hline (p-value) & & -0.92 \\
\hline
\end{tabular}

Note: see Table A1. 


\section{Appendix B - Data and sources}

The empirical analysis in this paper was undertaken on 20 manufacturing sectors classified according to the International Standard Industrial Classification of all economic activities (ISIC), Third Revision.

- The industry codes and definitions are the following:

17 Manufacture of textiles

18 Manufacture of wearing apparel; dressing and dyeing of fur

19 Tanning and dressing of leather; manufacture of luggage, handbags, saddlery, harness and footwear

20 Manufacture of wood and of products of wood and cork, except furniture; manufacture of articles of straw and plaiting materials

21 Manufacture of paper and paper products

22 Publishing, printing and reproduction of recorded media

23 Manufacture of coke, refined petroleum products and nuclear fuel

24 Manufacture of chemicals and chemical products

25 Manufacture of rubber and plastic products

26 Manufacture of other non-metallic mineral products

27 Manufacture of basic metals

28 Manufacture of fabricated metal products, except machinery and equipment

29 Manufacture of machinery and equipment, nec (not elsewhere classified)

30 Manufacture of office, accounting and computing machinery

31 Manufacture of electrical machinery and apparatus, nec

32 Manufacture of radio, television and communication equipment and apparatus

33 Manufacture of medical, precision and optical instruments, watches and clocks

34 Manufacture of motor vehicles, trailers and semi-trailers

35 Manufacture of other transport equipment

36 Manufacture of furniture; manufacturing, nec

- Variable definition and sources:

OPT: outward processing trade (temporary exports and re-imports) at current prices, from Eurostat, Comext database. Eurostat outward processing trade (OPT) is recorded only for extraEU trade. Therefore, in the geographical disaggregation of trade flows, "total" refers to flows between the EU country in question (Italy or Germany here) and all non-EU countries. 
"MedaEst" indicates a group of countries geographically close to the EU, whose wages are much below the EU average. In our classification, these countries are: Bulgaria, Czech Republic, Estonia, Lithuania, Latvia, Romania, Poland, Slovakia, Hungary, Armenia, Azerbaijan, Belarus, Georgia, Kazakhstan, Moldova, Russia, Tajikistan, Turkmenistan, Ukraine, Uzbekistan, Albania, Algeria, Bosnia, Croatia, Cyprus, Egypt, Gaza, Israel, Lebanon, Libya, Jordan, Macedonia, Morocco, Slovenia, Syria, Tunisia, Turkey, Yugoslavia.

Prod: industrial production at current prices. The sources were Conti economici delle imprese, Istat and Structural statistics for industry and services vol.1, OECD for Italy; Industrial Structural Statistics, OECD for Germany.

The index of fragmentation (F) was calculated as the ratio of re-imports of industry $j$ over domestic production of industry $\mathrm{j}$ (OPT/Prod).

Skill: number of managers and white-collar workers. The sources were Conti economici delle imprese, Istat for Italy and Produzierendes Gewerbe, Fachserie 4, Reihe 4.3, Statistisches Bundesamt for Germany.

Unskill: number of blue-collar workers. The sources were Conti economici delle imprese, Istat for Italy and Produzierendes Gewerbe, Fachserie 4, Reihe 4.3, Statistisches Bundesamt for Germany.

The index of skill intensity (S) was calculated as the ratio of white-collar over blue-collar workers (Skill/Unskill).

K: for Italy: net capital stock at constant prices. The source was OECD, Stan database; for Germany: gross capital stock at constant prices. The source was OECD, Stan database.

Y: for Italy: production at constant prices. The source was OECD, Stan database;

for Germany: value-added at constant prices. The source was OECD, Stan database. 


\section{Notes}

- We wish to thank Alessandro Sembenelli, Giovanni Bruno, Alan Deardorff, Juan Carlos Hallak and participants of the 4th ETSG Conference in Kiel, the FLOWENLA workshop in Vienna, the CHILD Workshop in Turin, University of Michigan RSIE participants, as well as three anonymous referees for comments and suggestions on previous versions of this paper. Financial support from the EU 5th Framework Program, Project FLOWENLA, N HPSE-CT2001-00064 is gratefully acknowledged.

* Cattaneo University - LIUC, rhelg@liuc.it

\# Politecnico di Milano and CESPRI - Bocconi University, lucia.tajoli@polimi.it

1 Many different terms have been used in the literature for this phenomenon: vertical integration, delocalization, production sharing, super-specialization are a few examples (see Arndt and Kierzkowski, 2001; Deardorff, 2001a; Hummels et. al., 2001; Feenstra, 1998) The proliferation of names indicates the interest raised by this form of production and trade. At the same time, the absence of a commonly accepted terminology suggests that the phenomenon is still ambiguously defined, as it is a relatively new and innovative aspect of the economic relations among countries.

2 Antràs and Helpman (2004) present a model showing that because of the trade-off between different types of costs, international fragmentation of production (or foreign outsourcing, in their terminology) will be convenient only for some categories of firms.

${ }^{3}$ For a detailed discussion, see Deardorff, 2001b.

${ }^{4}$ With more than two diversification cones, both production segments could be moved abroad, and the industry could even disappear from the country originally producing the final good. Alternatively, the comparative advantage in the maintained segment might be stronger than in the final good, and output of the fragmented industry might expand.

${ }^{5}$ Other models making different assumptions, but stressing the uncertainty of the effects of fragmentation on factor prices are developed by Feenstra and Hanson (2001) and Markusen and Venables (2003).

${ }^{6}$ Germany, in particular, is the country originating the largest share of European traffic for outward processing and it started to use this practice in some sectors more than a decade ago (see Baldone et al., 2001).

${ }^{7}$ Ideally, one should measure the relevance of IFP by comparing the value-added created abroad through OPT to domestically-produced value-added in the same industry. Unfortunately, the amount of valueadded embodied in re-imports is not available in the European statistics. One could try to compute such a figure from temporary exports and re-imports data, but not knowing the time lag occurring between the two flows and if temporary exports and the corresponding re-imports are registered in the same Nomenclature chapter, the risk is to introduce many distortions in the data. Therefore we prefer to use the available database.

${ }^{8}$ The available literature suggests that in continental Europe shocks primarily affect employment levels rather than wages. See for example Davis (1998).

${ }^{9}$ The presence of a sector selection in this phenomenon is important in explaining the effects observed in the labor market. Haskel and Slaughter (2002) also raise this point in a different context.

${ }^{10}$ Other important variables in choosing the outsourcing location can be distance, promptness in delivery and flexibility in the organization of production. See Evans and Harrigan (2003).

${ }^{11}$ On the changes in the use of skilled and unskilled labor in Italian manufacturing, see also Brenton and Pinna (2001).

${ }^{12}$ Following the discussion presented in section 2, we expect fragmentation to have a stronger impact on the labor market when the domestically-maintained production of the fragmented good displays a factor intensity which is very different from the country's average and when the fragmented good has a large share of consumers' expenditure.

${ }^{13}$ Eq. 2 can be obtained as a reparameterization of the cost-share equation. In fact, the log of the factorcost share can be written as: $\log \left(\mathrm{w}_{\mathrm{sk}} / \mathrm{w}_{\mathrm{unsk}}\right)+\log \left(\mathrm{S}_{\mathrm{sk}} / \mathrm{S}_{\mathrm{unsk}}\right)$. If we move the log wage ratio to the righthand side, we obtain Eq. 2 with the appropriate reparameterization.

${ }^{14}$ See the appendix for the exact definition of variables.

${ }^{15}$ This approach is different from most other studies that take first differences of the variables, but similar to Görg et al. (2001). 
${ }^{16}$ For comparison with the previous literature, results for the static specification are reported in Table A1 and $\mathrm{A} 2$ in the Appendix.

${ }^{17}$ This is a common practice in this literature. It is based on an assumption of perfect inter-industry labor mobility that would induce no cross-sectional wage variation: under this assumption the relative-wage variable can be dropped and its effect is captured by the constant term (see Berman et al., 1994). In our case, we have also estimated equ. [2] for Italy including the relative-wage term, with no substantial difference in the results (see Table A.4).

${ }^{18}$ For our small $\mathrm{N}$ and small $\mathrm{T}$ case, there are results (for example, Judson and Owen, 1999; Bun and Kiviet, 2005; Bruno, 2004) showing that there is no clear-cut ranking among the various estimators in terms of small-sample properties.

19 As a matter of comparison, we also report in table A.3 OLS estimates for the specification with no fixed effects and with only sector-fixed effects.

${ }^{20}$ Results on the capital variable should be interpreted with caution, because ideally one should use data on capital utilization rather than capital stock in this production function.

${ }^{21}$ Results for these control variables are in line with those obtained by Brenton and Pinna (2001) for the Italian case.

${ }^{22}$ Similar results are obtained by Görg et al. (2001) for the UK and by Anderton et al. (2001) for Sweden.

${ }^{23}$ Lack of data prevented us from replicating this exercise for Germany. 